\title{
The birth of the Serbian national music project under the influence of diplomacy
}

\author{
Vesna Peno, Goran Vasin
}

The aspiration to take a general perspective of the development of Serbian church and art music in the $19^{\text {th }}$ century within the broader sociopolitical and cultural context implies, according to recent findings, revision of the accepted theses in music historiography. One such recent scholarly endeavor ${ }^{1}$ has shed new light on the circumstances in which the Serbian national music program was initiated in Vienna, primarily associated in the second half of the $19^{\text {th }}$ century with the name Kornelije Stanković (see Appendix, Figure 1). This paper also shows that the Serbian "Enlightenment" in music at the time of rising nationalism(s) could be considered in the context of actual diplomatic activities that the church and political exponents of Orthodox nations took in the Habsburg capital. Structurally, there are two narratives that eventually meet toward the end of the paper. The first is related to the introduction of polyphony in Greek liturgical practice in Vienna. This music novelty gave rise to conflicting opinions expressed in the diplomatic dispatches that the Patriarch of Constantinople, residing in Fener, exchanged with Serbian Metropolitan Josif Rajačić (see Appendix, Figure 2), a church representative of all Orthodox citizens in Vienna. The second narrative in this paper follows the role that protopresbyter Mikhail Fyodorovich Raevsky (see Appendix, Figure 3), an influential Russian diplomat in Vienna, played in the creation of Pan-Slavic, therefore also Serbian, cultural politics and national music tendencies. Rajačić and Raevsky played important, if not decisive, roles in the overall social matrix from which Kornelije Stanković - not by chance and not exclusively owing to his artistic talent-entered the Serbian music stage. For this reason, particular attention is paid to these two figures, although there was a pleiad of high-ranking individuals in the Serbian circles of the time who contributed to the development, direction

\footnotetext{
1 Vesna Peno, "O višeglasju u bogoslužbenoj praksi pravoslavnih Grka i Srba: teološkokulturološki diskurs [On harmony singing in the religious practice of Orthodox Greeks and Serbs: A theological-culturological discourse]," Muzikologija 17 (2014): 129-154; Vesna Peno, Pravoslavno pojanje na Balkanu na primeru grčke i srpske tradicije: između Istoka i Zapada, eklisiologije i ideologije [Orthodox Chant in the Balkans on the Examples of Greek and Serbian Traditions: Between the East and West, Ecclesiology and Ideology] (Belgrade: Muzikološki institut SANU, 2016).
} 
and promotion of creative endeavors of the young Kornelije Stanković. ${ }^{2}$ The final part of the paper shows in what manner Stanković was praised for his musical mission during his short life with global and national importance, of which he was adamantly convinced.

Liturgical and particularly the church-music circumstances of Orthodox Christians in Vienna gave birth to a rare uniformity in the 1840s. On one hand, three nations-Greeks, Serbs and Russians-who shared the same faith, but whose church institutions had been burdened by many serious ecclesiastical issues for centuries, ${ }^{3}$ found themselves in ecclesiastical unison. On the other hand, an untypical encounter of Orthodox citizens of Vienna, who in many aspects had more differences than they had in common, occurred through liturgical music. The reason for their coming closer together was the introduction of four-part choral music in two churches in Vienna: the Trinity Church and the Church of St. George. ${ }^{4}$ In the mid-1840s, representatives of church boards in these two Greek Church communities ordered, not by accident, four-part sheets of liturgical chants from then very popular court composers/musicians Benedict Randhartinger (Chaviara $\&$ Randhartinger, 1844) and Gottfried von Preyer (Nikolaidou \& Preyer, 1845). ${ }^{5}$ Their scores (see Appendix, Figures 4 and 5) ${ }^{6}$ were performed by Austrian singers of the Vienna Opera, under the baton of Austrian conductor Joseph Griebel, on the most important Christian holidays-Easter and Pentecost-in 1844. ${ }^{7}$ Josif Rajačić, the Metropolitan of the Serbian Orthodox Church, celebrated these liturgies, with Greek and Russian priests as concelebrants. These festive liturgies in the Orthodox

\footnotetext{
2 The preliminary plan on conducting a broader, interdisciplinary examination of the connections of Kornelije Stanković with influential political figures that defended Serbian interests in AustriaHungary could not be realized due to reasonable causes. The data collected will be presented and systematized in a separate study.

3 Aleksandar Šmeman, Istorijski put pravoslavlja [The Historical Path of Eastern Orthodoxy] (Cetinje: Mitropolija Cetinjska-Atos, 1994).

4 On the enlightening motives of the Greek proponents of four-part singing and the inferiority complex of Balkan Greeks and Serbs regarding the unknown and alluring Austrian high art, particularly music traditions, see P. E. Formozes, Oi horodiakes ekdoseis tes ekklesiastikes mousikes se europaike mousike grafe stis duo orthodoxes elleneikes ekklesies tes Viennes [Editions of Choral Church Music in the European Music Notation in Two Greek Orthodox Churches in Vienna] (Thessaloniki: B. Regoupoulos, 1967); Giannes Filopoulos, Eisagoge stin ellenike polyphonike ekklesiastike mousike [Introduction to Greek Polyphonic Church Music] (Athens: Nefele Mousike, 1990); Peno, Pravoslavno pojanje na Balkanu, 63-67, 195-201.

5 The Greek authors of four-part scores presented manifestos on new musical trends in the prefaces of their publications. See Peno, Pravoslavno pojanje na Balkanu, 64-65.

6 The Greek text is romanized in the printed scores.

7 See P. E. Formozes, Oi horodiakes ekdoseis.
} 
temples were seen by the Vienna press in German, Greek and Serbian as cultural events par excellence, but also as ecclesiastical and political events of ecumenical importance. An additional reason for this was that, along with the "leading music figures of imperial court in terms of music," almost all dignitaries of Vienna's social milieu-representatives of different nations and confessions-also took part in the celebrations. ${ }^{8}$

The spiritual delight that the Orthodox and Roman Catholics of Viennaotherwise harshly divided by core national interests-shared on the occasion, was interpreted on the other side of the Balkans (considered in the broad sense), in Constantinople, as a betrayal of traditional values. An official epistle written in response and signed by members of the Greek Church Synod, headed by Ecumenical Patriarch Anthimus VI, was addressed in firstly to the Greek parishes in Vienna and Trieste, ${ }^{9}$ but also to all other local churches of the Orthodox world. ${ }^{10}$ The very epistle did not explicitly mention Slavic nations or the three centuries-long Russian tradition of polyphonic chant (and part songs). However, while Russians and their authentic music practice may have been neglected in Constantinople by chance, the Fener bishops did have in mind, along with their fellow Greeks, also Serbs, toward whom they had been exhibiting non-canonical ecclesiastical pretensions for an entire century. ${ }^{11}$

Rajačićs reply to the prelate of Constantinople concerning the "music novelties" in Vienna arrived with a two-year delay, after the so-called May Assembly of 1848 , on the occasion of which Rajačić was pronounced Patriarch. ${ }^{12}$ Not forgetting

8 See "Beč. Na Voskresenije [Vienna. On Easter]," Peštansko-budimski skoroteča 27 (1844): 159; M. Th., "O muzikalnom izobraženiju [On musical education]," Serbskij narodnij list 26 (1846): 202-206.

9 Greeks introduced harmony singing in Trieste in the same period.

${ }^{10}$ Engkuklios Patriarchike kai Sunodike Epistole katargousa kai apagoreusa ten kainotomon eisaxin kai chresin tes kainofanous tetrafonou mousikes en tes ierais akolouthiais ton apantachou orthodoxon ekklesion [Epistle of the Patriarchate and Synod condemning and proscribing the introduction and use of four-part music in the services of Orthodox churches] (Constantinople: Patriarchikes tou Genous Tupografio, 1846).

11 The Patriarchate of Constantinople non-canonically abolished the Patriarchate of Peć in 1776, threatening the autocephaly of the Serbian church. Although after the great migrations, Serbs north of the Sava and Danube were outside the sphere of influence of Constantinople territorially and in terms of ecclesiastical jurisdiction, pretensions from Fener extended beyond established boundaries. Patriarch Anthimus is known for his unjust approach to Slavic peoples in general, as well as despotic moves toward the Patriarchate of Alexandria.

12 On the same occasion, the Metropolitanate of Karlovci was, also nominally, raised to the level of Patriarchate. It has to be considered that these were only titular markers that were recognized by the Austrian emperor for political reasons, and were not the result of ecclesiastical law common to all official Orthodox churches. The canonical features of the Serbian Patriarchate were not recognized by other Orthodox churches, and the act of promulgation was interpreted particularly negatively in Constantinople. In correspondences with representatives of other Orthodox churches, Rajačić 
to point out that he himself was the Serbian archpriest and at the same time the archpriest of all Orthodox Christians in the Habsburg Empire, Rajačić did not miss the opportunity to acidly remind his Greek fellows of what he considered to be historical facts. He said that the Greek monophonic chant, referred to as "ancient and traditional" in the epistle, had little in common with the chant that Slavs, seeking "true faith," once heard in the Church of Hagia Sophia and made them so elevated that they "received Christianity from the Greeks." ${ }^{13}$ Rajačić was referring here to the emissaries of Russian Prince Vladimir in the late $10^{\text {th }}$ century, who were so impressed by the chanted church services in Constantinople that they revealed to their ruler how God was with the Romaioi, the people who praised him more beautifully than the Khazars, Mohammedans or Latins. ${ }^{14}$

Some might say this remark in the entirely cynical latter was not deliberate. Nevertheless, this vague reference to the Slavic, that is, Russian brethren who, attracted by chanting, joined the eastern Christian family, had a specific purpose. The Serbian political and church leader's affiliation with the Russian Ministry of Foreign Affairs and the Russian Church Synod was at the time particularly strong. ${ }^{15}$ Attempting to strengthen the shaken Serbian position in the Habsburg monarchy and restore church life, while also trying to stay above the proactive movements of Serbian middle-class youth in a non-coreligionist empire, Rajačić enjoyed strong support of Mikhail Fyodorovich Raevsky (1811-1884), who had been serving at the Russian Consulate in Vienna since 1842. The entire Russian diplomatic mission to help the Serbs on both sides of the Danube, but also across the Drina, all the way to Dalmatia and Montenegro, was organized by the Russian protopresbyter. His huge experience as a priest, ${ }^{16}$ and his multiple Pro-Slav engagements made him the head of Russian Church and a political hub for the Habsburg monarchy and the Balkans. ${ }^{17}$ Namely, Raevsky maintained relations with all leading Slavic

continued to be addressed as Metropolitan, and this was typical until the 1919 unification of the Serbian Patriarchate.

${ }^{13}$ Josif Rajačić, Svjatjejšemu vostočnija pravoslavnija Cerkvi Patriarhu Konstantinopolskomu Antimu v Požunje [To the Holy Patriarch of the Eastern Orthodox Church in Constantinople], Archive of the Serbian Academy of Sciences and Arts in Sremski Karlovci, MP-A 293-1848.

${ }^{14}$ Lavrentyevski letopis f. 37r, see http://litopys.org.ua/lavrlet/lavr05.htm\#lyst37.

${ }^{15}$ After the suffering of Serbs in war conflicts with Hungarians in 1848-1849, the ties with the Russian court and the Synod of the Russian Church strengthened even further.

${ }^{16}$ Before coming to Vienna, Raevsky served as a diplomat in Stockholm. See Nikola Petrović, "Dvadeset pisama Kornelija Stankovića Mihailu F. Rajevskom [Twenty letters from Kornelije Stanković to Mikhail F. Raevsky]," in Kornelije Stanković i njegovo doba, edited by Dimitrije Stefanović (Belgrade: Muzikološki institut SANU, 1985), 74.

17 The impressive list of Raevsky's correspondents that bears evidence to his abundant diplomatic activities includes the Russian consuls from Mostar, Rijeka (L. Berezin), Dubrovnik, Belgrade, Ioannina and Constantinople, Russian priests in various European capitals, and above all, the leading political figures and representatives of the Russian aristocracy, part of who were interested 
representatives in the Habsburg capital as well as elsewhere in the Empire, in the Principality of Serbia and in the Ottoman Empire who focused on the affirmation of national programs that concerned both the state and church. Not surprisingly, the Russian mission did not only go one way, merely fulfilling the expectations of fellow Slavs. Raevsky acted primarily on the foreign policy interests of his state and his Church when conducting specific activities directed toward cultural, educational and political emancipation of Serbs, Croats, Slovenes, Czechs and Bulgarians. ${ }^{18}$

A segment of his personal sphere of interest, as well as of his like-minded compatriots, was music. ${ }^{19}$ Common church chants, along with the common Old Church Slavonic language, could have additionally strengthened existing bonds between Russians and Serbs. More open Greeks in Vienna were also not indifferent to the specific, "Russian" church music style, of which the authors of prefaces and arrangers of the four-part liturgies by Randhartinger and von Preyer did not directly speak, but Josif Rajačić mentioned openly in his epistle to the Patriarch of Constantinople. In his reply to Fener regarding the events in 1844, he pointed out that not only did choral music not diminish, but on the contrary, it fostered unity at church services between Greeks, Serbs and Russians who found themselves in joint prayers in Vienna. The highest Orthodox Church official in the Austrian capital had a reason to feel diplomatically superior to the Patriarch of Constantinople, at least when it comes to the institutionalization of music reform in Orthodox temples in Austria. With such a feeling, he allowed himself to remind the first among the bishops of Constantinople ${ }^{20}$ of the far more complex problems among Christians in the Balkans that needed to be tackled before chant issues. ${ }^{21}$

in the "Serbian question," such as Count Dmitry Nikolaevich Bludov (1785-1864), a diplomat, president of the State Council of the Russian Empire and a great patron of the arts, and his daughter, countess Antonina Bludova (1813-1891), a writer and a close friend of Empress Maria Alexandrovna. See V. Matula, I. V. Čurkina, Zarubežnie Slavjane i Rossi, Dokumenti Arhiva M. F. Raevskoga 40-80-godi 19. veka [Slavs and Russians Abroad, Documents from the Archive of M. F. Raevsky 1840s-1880s] (Moscow: Nauka, 1975), 46-59.

18 Particularly during the period of forced Germanization of non-Austrian inhabitants of the empire, Raevsky played a great role in the spreading of Russian language among Slavs, using his wide network of contacts. His actions included publishing Russian textbooks, and historical reviews and reports on the political and cultural circumstances on the Balkans, which is confirmed in his prolific correspondence with the first person of the Moscow synodal publishing house, P. Bezonov, as well as the longstanding consul in the Bosnian Pashaluk, Slavicist Alexander Hilferding, and numerous Slavic cultural and political activists. Ibid., 35, 123-138.

${ }^{19}$ Balakyrev wrote to Raevsky several times from Prague on the importance of Russian art music among Czechs. Ibid., 27-29.

${ }^{20}$ In that time, the bishops of Constantinople were still responsible for the Serbs of Bosnia and Herzegovina and Old Serbia.

${ }^{21}$ Rajačić openly pointed to the Hellenic propensity for power, hypocrisy and corruption in his addresses to Patriarch Anthimus VI. Raevsky regularly received reports from Russian consuls on Greek bishops' unfortunate treatment of Serbs, particularly from Bosnia and Herzegovina, which 
In circumstances where each and every capacity needs to be recognized and utilized in efforts for national enlightenment and development, but also striving for Pan-Slavic unity, liberation from non-coreligionist government and non-canonical primacy of Constantinople in the not-yet-freed Serbian regions, the emergence of a talented young musician like Kornelije Stanković—his patron was Pavle Riđički (1805-1893), a well-respected landowner, industrialist and nobleman, a member of Matica srpska (since 1837) and author of the Constitution of the short-lived Serbian Vojvodina (1849) - could not have gone unnoticed. At Riđički's home, Stanković had the opportunity to meet, even before going to Vienna, the most prominent social and cultural activists among Serbs in Pest who were holding key positions in national and church assemblies and were directly involved with Patriarch Rajačić, as well as with leaders in the Principality of Serbia, officials of the Vienna court and Russian bearers of the idea of a Pan-Slavic revival. ${ }^{22}$ In a circle of true friends and like-minded university colleagues-closest to Stanković were philologist Jovan Bošković, painter Stevan Todorović, historian Fedor Demelić and Mihail Polit Desančić, a publicist, lawyer and politician-this young musician joined the all-national revival and Pan-Slavic mission with romantic zeal.

Judging by the letters he exchanged with Raevsky, Stanković started putting church and folk tunes on paper precisely on the initiative of his Russian patron. ${ }^{23}$ It is from him that he learned about the endeavors of Alexei Fyodorovich Lvov (1790-1870), a Russian violinist, composer and conductor who as the head of the Sankt Petersburg Court Chapel published a four-part harmonization of a well-known chant in 1839. No less, if not more, important was Patriarch Rajačićs encouragement for Stanković, since this young artist was the Patriarch's advantage the Greeks did not have: a man of their own kin and creed, educated on European

included forbidding to use their mother tongue in prayers. He then shared the information with the Russian Synod and Court, in which the Orthodox peoples outside their own homeland put their hopes of liberation.

22 We refer to the doctor of philosophy, writer and editor of the journal Letopis Matice srpske (1842-1847; 1850-1853), Jovan Subotić. In 1848, he initiated the formulating of Serbian requests before the "assembly" of Serbs in Pest. He was also a representative of Serbs in Pest on the May Assembly in Sremski Karlovci, where he was elected member of the Constitutional Board. Apart from Subotić, Riđički was also close friends with Konstantin Bogdanović (1811-1854), a lawyer, secretary of the State Council and member of the Society of Serbian Intellectuals in the Principality of Serbia. He was the personal secretary of Rajačić, maybe even in the year when the letter on choral music was sent to Constantinople. In the circle around Riđički, Kornelije Stanković also had the chance to meet Đorđe Stojaković (1811-1863), a lawyer from Pest, member of the Constitutional Board of the Serbian Vojvodina, a political advisor of Prince Miloš and Prince Mihailo Obrenović, and since 1856 a counselor of Vienna's highest court.

${ }^{23}$ Vesna Peno, “Jednoglasni zapisi crkvenog pojanja Kornelija Stankovića [Kornelije Stankovićs monophonic transcriptions of church chants]," in Tradicija kao inspiracija, edited by Sonja Marinković, Sanda Dodik (Banja Luka: Akademija nauka i umjetnosti Republike Srpske, Muzikološko društvo Republike Srpske, 2015), 199-211. 
premises, who was capable of putting chants previously fostered only through oral tradition into European notation and four-part choir sheets. Their attentive and strict evaluation of Stankovićs first works and insistence on close scrutiny of his scores prior to public performance spoke volumes of the fact that it was vital for both Rajačić and Raevsky that Stanković's work reflect traditional singing. ${ }^{24}$

With the support of influential figures, and confident that it was his task to bring to public attention unknown treasures of Serbian folk music, Stanković succeeded in becoming an acclaimed national music leader ${ }^{25}$ in the course of his short life. His numerous concerts attracted large audiences and were praised in the press on both sides of the Danube and Drina. Eventually, renowned Russian contemporaries became interested in Stanković's work, such was the aforementioned Lvov, or following the composer's death also Vladimir Fyodorovich Odoyevsky, a Russian prince, the founder of the Russian Music Society and the Conservatorium in Moscow, as well as a close associate of Dmitry Razumovsky, a reputable Russian mediaevalist and ancient Russian chant scholar.

That Stanković was recognized as a Serbian music missionary among his contemporaries due to his multi-layered and diversely directed Russian-Serbian and Pan-Slavic diplomatic activities was confirmed with his nomination for the Order of St. Stanislaus, $3^{\text {rd }}$ class. For this award he was endorsed by protopresbyter Raevsky on September 8, 1862, on the occasion of the celebration of 1000 years

\footnotetext{
24 See Appendix, Figure 6. Both Stankovićs liturgies were performed with the patriarch's blessing during services he celebrated. The first four-part Liturgy was sung by a mixed choir on the second day of Easter in Patriarch Rajačićs home chapel. See Đorđe Perić, "Bibliografija Kornelija Stankovića [The bibliography of Kornelije Stanković]," in Kornelije Stanković i njegovo doba, 289. In a letter to Pavle Riđički from April 27, 1851, the composer states that the Liturgy was performed in the Greek church on Easter the same year in the presence of the patriarch and a great crowd of believers: "Greeks, Russians, Serbs and Germans, including composer Simon Sechter." Although without directly saying so, Stanković reveals that his Liturgy was presented by mentioning that "Christ Is Risen sounded for the first time." See Ivanka Veselinov, "Iz prepiske Kornelija Stankovića [From Kornelije Stanković's correspondence]," in Kornelije Stanković i njegovo doba, 87. In a letter from May 11, 1858, Karlovci Archpriest Atanasije Popović, whom the patriarch charged with monitoring Stanković's work, reported to Rajačić that at the Pentecost celebration in the Russian church in Vienna the vespers were served "with our chants, to the pleasure and joy of the numerous Orthodox believers." See Archive of the Serbian Academy of Sciences and Arts in Sremski Karlovci, ASANUSK MP-A 517-1858, according to Dimitrije Stefanović, "Prilog proučavanju notnih autografa, arhivskih i drugih dokumenata o Korneliju Stankoviću [A contribution to the study of musical autographs, archival and other documents about Kornelije Stanković]," in Kornelije Stanković i njegovo doba, 124). On Serbian the chants collected in Karlovci and Stanković's choir arrangements performed on Easter and Pentecost in the Russian chapel in Vienna, the journal Srbski dnevnik (Serbian daily) reported in 1858. See Milana Bikicki, "Kornelije Stanković u vojvodjanskoj štampi [Kornelije Stanković in the press of Vojvodina]," in Kornelije Stanković i njegovo doba, 212.

${ }^{25}$ Stanković's works were, along with advertisements in the Serbian press, subject to valuable subscriptions.
} 
of Russian statehood in Novgorod. ${ }^{26}$ This award from the Russian side was an additional motive for Belgrade Metropolitan Mihailo Jovanović, who studied in Russia and was closely associated with Raevsky, to put in a good word for the young artist in the Principality of Serbia. ${ }^{27}$

The fact that diplomatic dispatches with information on the activities of influential Austrian citizens of Serbian origin circulated quite well between Belgrade and Vienna—not only between Vienna and Sankt Petersburg — and were tightly linked to Russian diplomatic activities may be confirmed by one report of the Austrian consul in Belgrade. He sent a note to the Ministry of Foreign Affairs in Vienna proposing that Stanković be awarded the Knight's Cross of the Imperial Austrian Order of Franz Joseph. It is curious that this proposal came a year before the Serbian musician was decorated by the Russians. ${ }^{28}$ In a conspicuous excerpt from the dispatch, the consul described that an imperial subject, Kornelije Stanković, was the only person among Serbs who dedicated himself professionally to music, choosing it as his life purpose. For a nation like Serbs, in which noble arts and crafts were so underdeveloped, this was such an odd and curious occurrence that he humbly dared not go in further detail or even think of providing more information to his Imperial Highness ${ }^{29}$. Drawing attention to Stankovićs close relationship with Riđički, who had recently been awarded with the highest grace by his Imperial Highness, as well as his successful studies with Sechter, which attracted attention of Patriarch Rajačić, the Austrian consul emphasized that it was this church dignitary who assigned Stanković the "arduous task of collecting and arranging Serbian (Eastern Orthodox) chants living only in oral tradition into four-voice scores by following strict scholarly rules." ${ }^{30}$ Having confirmed that the Serbian musician was

\footnotetext{
${ }^{26}$ On the same occasion, Metropolitan Mihailo Jovanović (1826-1898) was awarded the Order of St. Anna, $1^{\text {st }}$ class, while Vuk Karadžić, Jovan Subotić and Jovan Hadžić were given the Order of St. Anna, $2^{\text {nd }}$ class.

${ }^{27}$ Metropolitan Jovanović was one of Stankovićs many patrons. An ardent supporter of PanSlavism, who led the Serbian Church in accordance with the diplomatic directions of the Russian state and Church of the late $19^{\text {th }}$ century, he admired Russian church music as well as Stankovićs musical undertakings. He advocated for prince Mihailo Obrenović to open a department for multi-part church singing in Belgrade. He also financially supported the publishing of Stankovićs Liturgy, which was printed in Vienna in 1862. (Mirka Pavlović, "Zaostavština Kornelija Stankovića [Kornelije Stanković's manuscripts]," in Kornelije Stanković i njegovo doba, 166; Dimitrije Stefanović, "Mitropolit Mihailo i Kornelije Stanković [Metropolitan Mihailo and Kornelije Stanković]," in Život i delo mitropolita Mihaila (1826-1898), edited by Dimitrije Stefanović (Belgrade: SANU, 1994), 299-300. About the cooperation between Stanković and Metropolitan Mihailo Jovanović, see also Peno, Pravoslavno pojanje na Balkanu, 118.

28 The report with the mentioned proposal was written on June 19, 1861.

${ }^{29}$ V., "Izveštaj," Muzički glasnik 9 (1922): 5-6.

${ }^{30} \mathrm{Ibid}$. The consul also referred to Stankovićs fundraising performance for the construction of a Serbian church in Vienna in 1862, which was well received by Viennese art critics, and announced his journeys across Serbia, Croatia and Dalmatia with an aim of collecting folk songs.
} 
a politically and morally upstanding imperial subject, the consul also presented the actual political motives behind his proposal: "in this politically convenient moment, an opportunity has arisen to award not only Stanković for his merits in music, but the entire Serbian community in Austria. The main task given to this very talented young man, to collect, put into four-part choir scores and publish all liturgies of the Eastern Orthodox Church, is a chance which, bearing in mind the well-known character of Orthodox Christians, will not pass without particular interest of priests and the common people as well [...]. It seems politically significant that such a task is carried out by an Austrian subject with German education, because his work, unique as it is, cannot be limited to the area of the Patriarch of Karlovci, but will influence all Slavic Orthodox churches." ${ }^{11}$ In the final part of his dispatch, the Austrian diplomat fully revealed the reasons why the Serbian musician should be decorated, stating that such an act of political thoughtfulness, to indulge Austrian Serbs with rights regarding their faith in every possible way, was aimed at turning away their priests from Russia, whose propaganda in religious and political issues, conducted in a fickle manner, had to be reduced in significance and essence as Austrian Serbs gained more national and ecclesiastical independence. ${ }^{32}$

What happened after the dispatch is well known: Stanković did not receive the Knight's Cross of the Order of Franz Joseph, nor did he manage to visit Russia due to his advanced illness, despite his fervent wish to get to know the Russian chant from its very source, and to present his work to Russians himself. His musical diplomatic mission among South Slavs, particularly Croats, lasted as long as he was popular and famous, as long as they saw any use in him. Nevertheless, his work and legacy gained wide acclaim ${ }^{33}$ already by the end of the $19^{\text {th }}$ century when liturgical music of the Serbian Church and on concert stages was canonized by the work of another socially very prominent musician, Stevan Stojanović Mokranjac. ${ }^{34}$ But regardless of how much the work of the first learned Serbian musician was overshadowed by the socially, diplomatically and musically superior Mokranjac, ${ }^{35}$ it is undeniable that Stanković, under the influence of his patrons, initiated the shift in Serbian church music from Eastern monophony toward Western polyphony. Russian

\footnotetext{
31 It is obvious that the Austrian consul was convinced in what Stanković believed-that his harmonizations of "the most beautiful Serbian melodies of all of Orthodoxy will be heard in the churches of other Christian peoples." See Fedor Demelić, "Kornelije Stanković," Letopis Matice srpske 39/110 (1867): 210 (188-234).

32 V., "Izveštaj," 6.

${ }^{33}$ See Pavlović, "Zaostavština Kornelija Stankovića."

${ }^{34}$ Vesna Peno, Ivana Vesić, "From Myth to Reality: Stevan Stojanović Mokranjac and Serbian Church Music," Musicological Annual 54/1 (2018): 49-58.

${ }^{35}$ See Biljana Milanović (Ed.), Stevan Stojanović Mokranjac (1856-19014). The Belgrade Choral Society Foreign Concert Tours (Belgrade: Institute of Musicology SASA, Serbian Musicological Society, 2014).
} 
church music had already taken this course three centuries earlier, which is why the emergence of harmonization of the one-voice/one-part chant, which has been considered "Serbian" ever since, was easily marked and accepted as traditional. 36 There is no doubt that emergence of choral "Serbian folk" church music was one of the outcomes of the general political and cultural tendencies, in which one can follow reliable traces of diplomatic activities. These aspects accentuate the position uttered at the beginning of this paper about revising the pages written in Serbian music historiography on musicians whose more or less transparent diplomatic engagement left a mark on Serbian church music.

\footnotetext{
${ }^{36}$ In the preface to his Liturgy, Stanković wrote a sort of national music manifesto, explaining his reasons for using a multi-part choral arrangement in which he incorporated folk tunes. See Kornelije Stanković, Pravoslavno crkveno pojanje u srbskog naroda I [Orthodox Chant of the Serbian People I] (Vienna, 1862; phototype edition, edited by Danica Petrović, Belgrade-Novi Sad: SANU, Narodna biblioteka Srbije, Matica srpska, 1994).
} 


\section{References:}

“Beč. Na Voskresenije." Peštansko-budimski skoroteča 27 (1844): 159. [Orig. in Serbian Cyrillic]

Bikicki, Milana. "Kornelije Stanković u vojvodjanskoj štampi.” In Kornelije Stanković $i$ njegovo doba, edited by Dimitrije Stefanović, 205-225, Belgrade: Muzikološki institut SANU, 1985. [Orig. in Serbian Cyrillic]

Demelić, Fedor. "Kornelije Stanković." Letopis Matice srpske 39/110 (1867): 188-234. [Orig. in Serbian Cyrillic]

Engkuklios Patriarchike kai Sunodike Epistole katargousa kai apagoreusa ten kainotomon eisaxin kai chresin tes kainofanous tetrafonou mousikes en tes ierais akolouthiais ton apantachou orthodoxon ekklesion. Constantinople: Patriarchikes tou Genous Tupografio, 1846.

Filopoulos, Giannes. Eisagoge stin ellenike polyphonike ekklesiastike mousike. Athens: Nefele Mousike, 1990.

Formozes, P. E. Oi horodiakes ekdoseis tes ekklesiastikes mousikes se europaike mousike grafe stis duo orthodoxes elleneikes ekklesies tes Viennes. Thessaloniki: B. Regoupoulos, 1967.

Lavrentyevski letopis f. 37r, http://litopys. org.ua/lavrlet/lavr05.htm\#lyst37.

M. Th. “O muzikalnom izobraženiju.” Serbskij narodnij list 26 (1846): 202-206. [Orig. in Serbian Cyrillic]

Matula, V., Čurkina, I. V. Zarubežnie Slavjane i Rossi, Dokumenti Arhiva M. F. Raevskoga 40-80-godi 19. veka. Moscow: Nauka, 1975. [Orig. in Russian Cyrillic]

Milanović, Biljana (Ed.). Stevan Stojanović Mokranjac (1856-19014). The Belgrade Choral Society Foreign Concert Tours. Belgrade: Institute of Musicology SASA, Serbian Musicological Society, 2014.
Pavlović, Mirka. "Zaostavština Kornelija Stankovića." In Kornelije Stanković i njegovo doba, edited by Dimitrije Stefanović, 123-135, Belgrade: Muzikološki institut SANU, 1985. [Orig. in Serbian Cyrillic]

Peno, Vesna. "O višeglasju u bogoslužbenoj praksi pravoslavnih Grka i Srba: teološkokulturoloski diskurs.” Muzikologija 17 (2014): 129-154. [Orig. in Serbian Cyrillic]

Peno, Vesna. "Jednoglasni zapisi crkvenog pojanja Kornelija Stankovića." In Tradicija kao inspiracija, edited by Sonja Marinković, Sanda Dodik, 199-211. Banja Luka: Akademija nauka i umjetnosti Republike Srpske, Muzikološko društvo Republike Srpske, 2015. [Orig. in Serbian Cyrillic]

Peno, Vesna. Pravoslavno pojanje na Balkanu na primeru grčke i srpske tradicije: između Istoka i Zapada, eklisiologije $i$ ideologije. Belgrade: Muzikološki institut SANU, 2016. [Orig. in Serbian Cyrillic]

Peno, Vesna, Vesić, Ivana. "From Myth to Reality: Stevan Stojanović Mokranjac and Serbian Church Music." Musicological Annual 54/1 (2018): 49-58.

Perić, Đorđe. "Bibliografija Kornelija Stankovića.” In Kornelije Stanković i njegovo doba, edited by Dimitrije Stefanović, 287-326. Belgrade: Muzikološki institut SANU, 1985. [Orig. in Serbian Cyrillic]

Petrović, Nikola. "Dvadeset pisama Kornelija Stankovića Mihailu F. Rajevskom.” In Kornelije Stanković i njegovo doba, edited by Dimitrije Stefanović, 73-83. Beograd: Muzikološki institut SANU, 1985. [Orig. in Serbian Cyrillic] 
Rajačić, Josif. Svjatjejšemu vostočnija pravoslavnija Cerkvi Patriarhu Konstantinopolskomu Antimu v Požunje, ASANUSK, MP-A 293-1848. [Orig. in Serbian Cyrillic]

Stanković, Kornelije. Pravoslavno crkveno pojanje u srbskog naroda I, Vienna, 1862. phototype edition, edited by Danica Petrović, Belgrade-Novi Sad: SANU, Narodna biblioteka Srbije, Matica srpska, 1994. [Orig. in Serbian Cyrillic]

Stefanović, Dimitrije. "Prilog proučavanju notnih autografa, arhivskih i drugih dokumenata o Korneliju Stankoviću." In Kornelije Stanković i njegovo doba, edited by Dimitrije Stefanović, 123-135. Belgrade: Muzikološki institut SANU, 1985. [Orig. in Serbian Cyrillic]
Stefanović, Dimitrije. "Mitropolit Mihailo i Kornelije Stanković." In Život i delo mitropolita Mihaila (1826-1898), edited by Dimitrije Stefanović, 293-304. Belgrade: SANU, 1994. [Orig. in Serbian Cyrillic]

V., "Izveštaj." Muzički glasnik 9 (1922): 5-6. [Orig. in Serbian Cyrillic]

Veselinov, Ivanka. "Iz prepiske Kornelija Stankovića." In Kornelije Stanković i njegovo doba, edited by Dimitrije Stefanović, 85-102. Belgrade: Muzikološki institut SANU, 1985. [Orig. in Serbian Cyrillic]

Šmeman, Aleksandar. Istorijski put pravoslavlja. Cetinje: Mitropolija Cetinjska, Atos, 1994. [Orig. in Serbian Cyrillic] 


\section{APPENDIX}

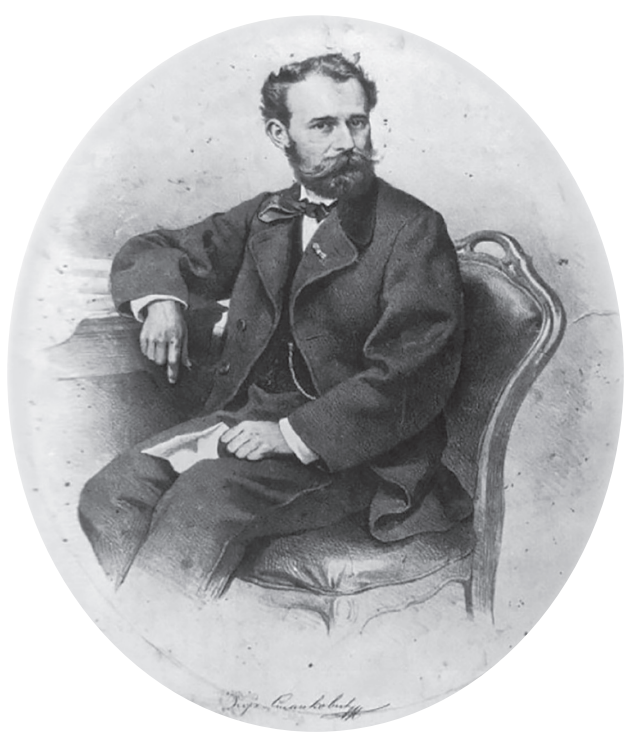

Figure 1.

Kornelije Stanković (1831-1865),

https://www.medias.rs/kornelije-stankovic-kompozitor-pijanista-i-horovodja.

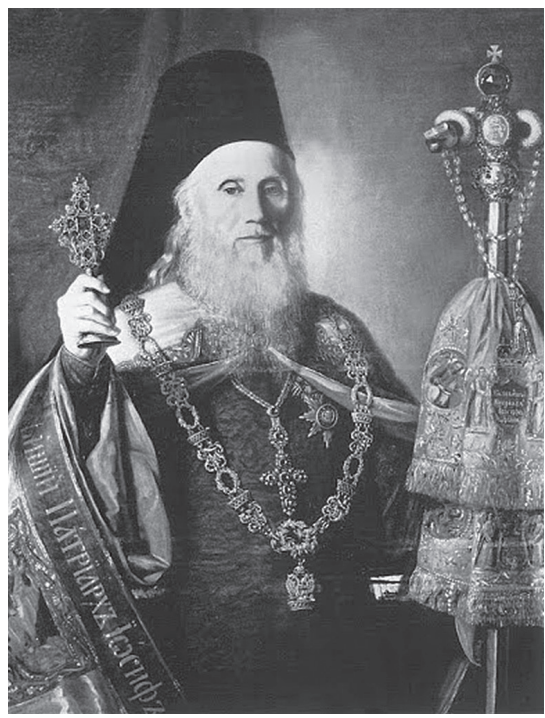

Figure 2.

Josif Rajačić, the Metropolitan of Karlovci and Serbian Patriarch (1785-1861), www.riznicasrpska.net.

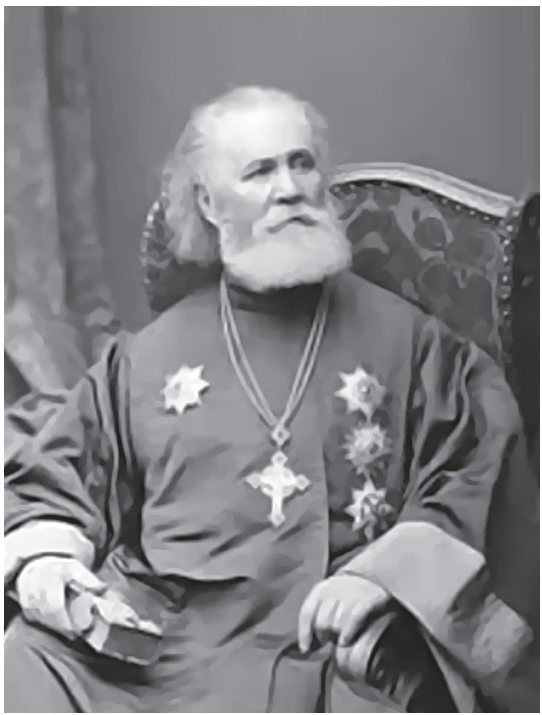

Figure 3.

Mikhail Fyodorovich Raevsky, archpriest (1811-1884), stated in Wikimedia. 
xopós No. KK. 'O Xtpovizsis 'T'upos.

iz- Andrate.

(2)

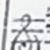

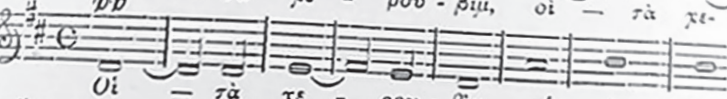

(2)

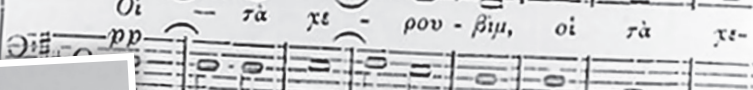

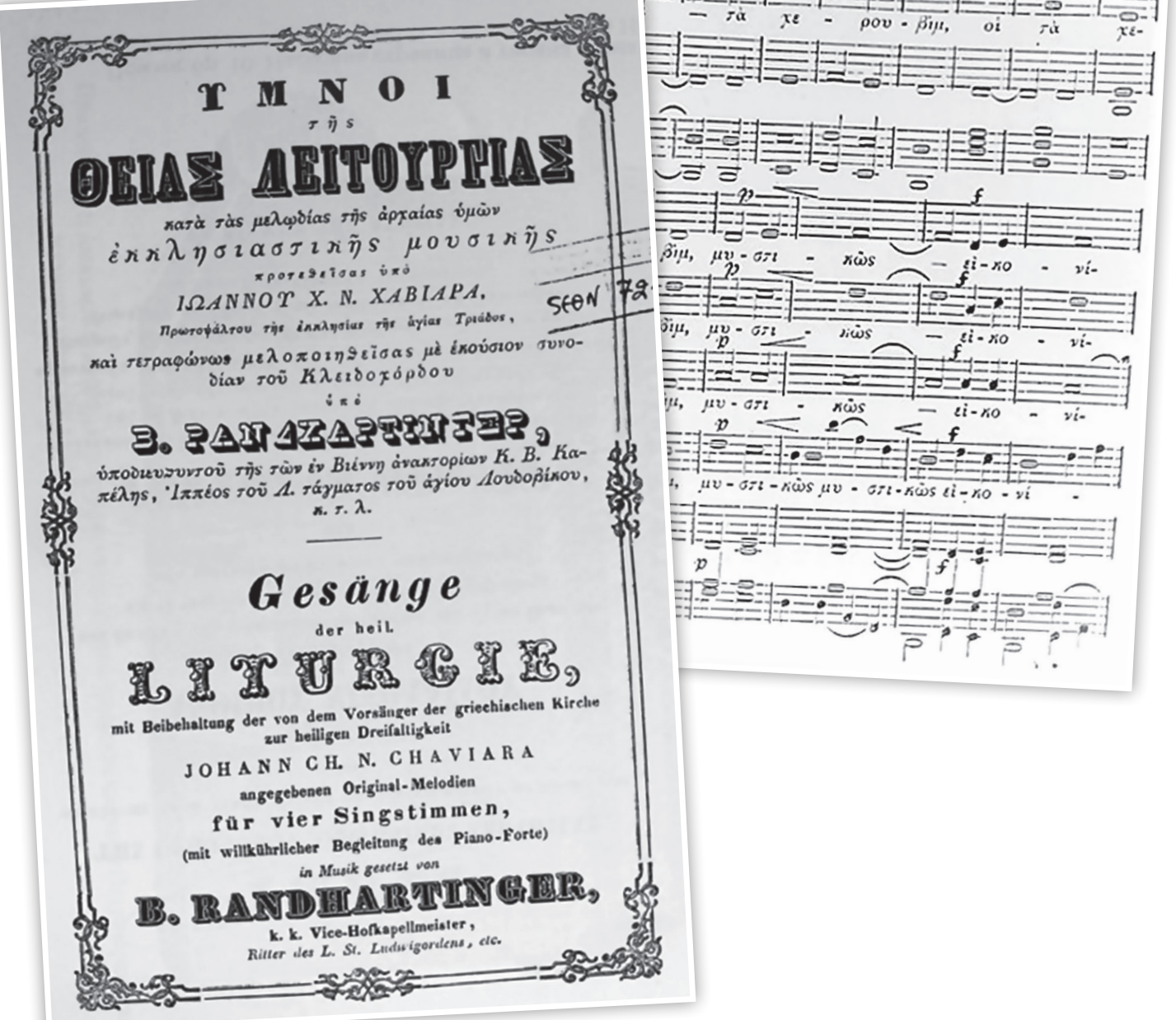

Figure 4 .

Cover page and excerpt from the score of Benedict Randhartinger's Liturgy. 


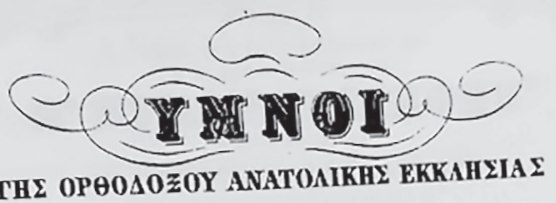

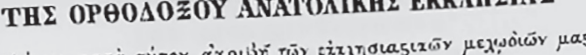

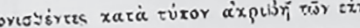
$\dot{0} \geq 0^{\circ}$

\section{AVOIMOY NIKOAAIIAOY}

Teropespizos,

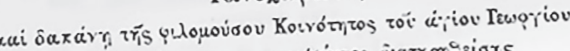

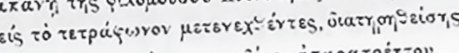

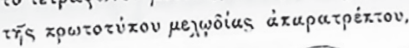

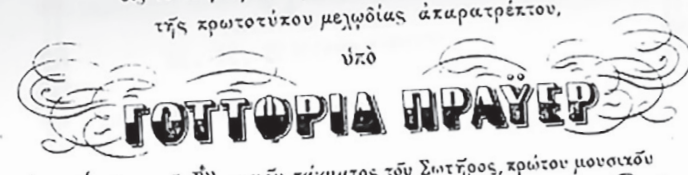

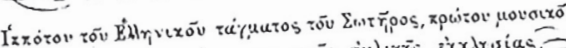

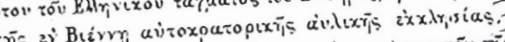

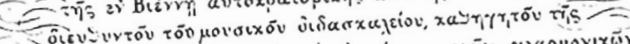

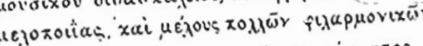
Eт

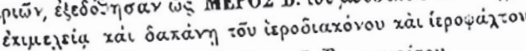

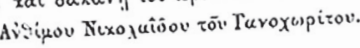

È BIÉNNH TḦ̌ AYYsPIAE

1847.

Figure 5.

Cover page and excerpt from the score of Gottfried von Preyer's Liturgy. 


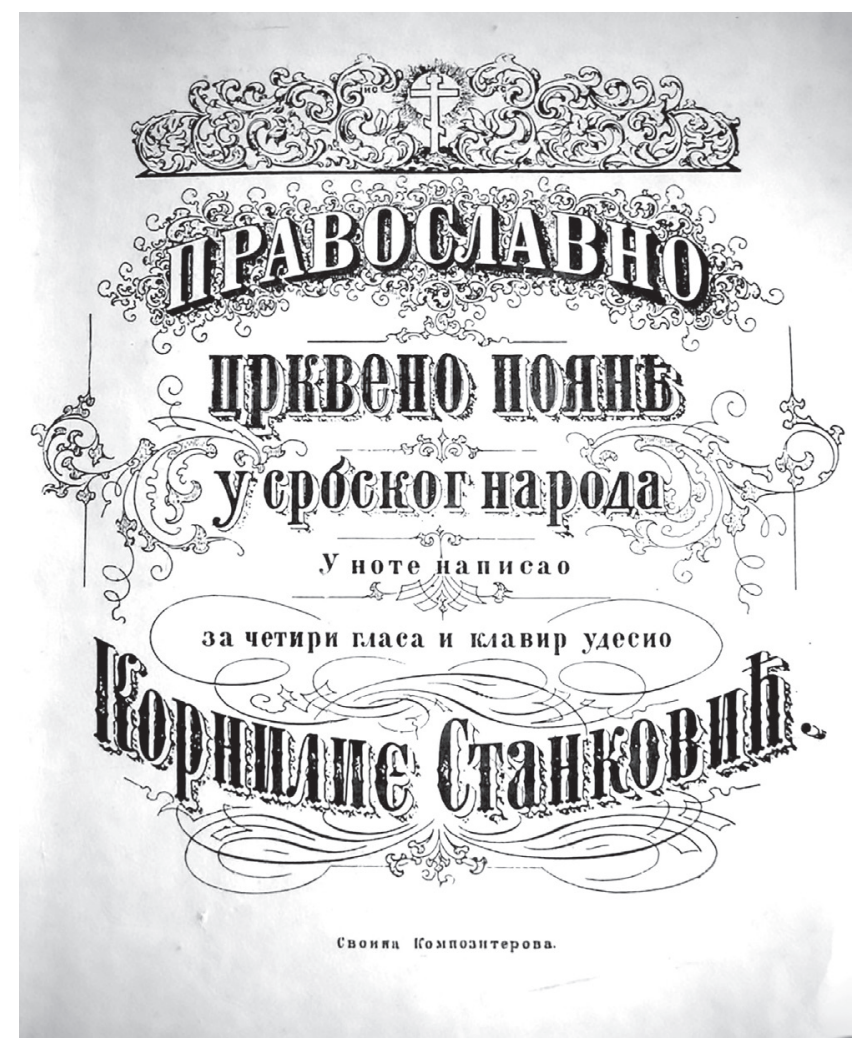

Figure 6.

Cover page of Kornelije Stanković's

Pravoslavno crkveno pojanje u srbskog naroda. 